\title{
HOW COULD HOME-BASED JOINT ACTIVITIES CONTRIBUTE TO CHILDREN'S DEVELOPMENT?
}

\author{
THE IMPACT OF PARTICIPATORY ART AND READING \\ ACTIVITIES ON THE CAREGIVER-INFANT RELATIONSHIP, \\ PROSOCIALITY AND THE DEVELOPMENT OF SELF-CONCEPT
}

\section{Szerző:}

Valuch Mariann

Kocka Kör

A szerző e-mail címe:

valuchmariann@gmail.com

\section{Lektorok:}

Estefánné Varga Magdolna (Ph.D.)

Eszterházy Károly Egyetem

Mező Katalin (Ph.D.)

Debreceni Egyetem

és további két anonim lektor...

\begin{abstract}
The goal of the current study is to give a theoretical background on how home based activities could have positively affect children's development, with a special focus on the following areas: attachment relationship, prosociality and the development of selfawareness. The study discusses the main theoretical backgrounds of each potential predictors (namely: attachment, prosociality and development of self-concept) and their relations with participative arts and reading.

Keywords: parental attachment, participative art, joint reading, prosocial behaviour, self- awareness, development of the self-concept

Discipline: psychology, pedagogy

\footnotetext{
Absztrakt

HOGYAN JÁRULHATNAK HOZZÁ AZ OTTHONI JÁTÉKOS, KREATÍV FOGLALKOZÁSOK A GYERMEKEK PSZICHOLÓGIAI FEJLŐDÉSÉHEZ? A KREATÍV ALKOTÓI TEVÉKENYSÉG ÉS AZ OLVASÁS HATÁSA A SZÜLÖGYEREK KAPCSOLATRA, A PROSZOCLÁLIS VISELKEDÉS ALAKULÁSÁRA, ILLETVE AZ ÉN-TUDATOSSAGG FEJLŐDÉSÉRE.
} 
Jelen tanulmány célja, hogy egy elméleti összefoglalót adjon, arról, hogyan járulhatnak hozzá az otthoni keretek között végzett, játékos, alkotó folyamatok és az olvasás a gyermekek pszichológiai fejlődéséhez. A tanulmányban részletes bemutatásra kerülnek az egyes prediktorokhoz (kötődés, proszociális viselkedés, én tudatosság) tartozó elméletek, valamint kapcsolatuk a kreatív tevékenységekkel és az olvasással.

Kulcsszavak: fejlődéspszichológia, kreatív foglalkozás, olvasás, kötődés, proszociális viselkedés, én-tudatosság

Diszciplínák: pszichológia, pedagógia

Valuch Mariann (2021): How could home-based joint activities contribute to children's development? The impact of participatory art and reading activities on the caregiverinfant relationship, prosociality and the development of self-concept. OxIPO folyoirat, V. évf. 2021/1. szám, 65-79. DOI: 10.35405/OXIPO.2021.1.65

\section{Introduction}

John Bowlby's attachment theory (1973) emphasised the importance of reciprocal experiences shared between the child and his/her caregiver. According to his theory, humans have derived to enhance experience-based mental representations of attachment relationships (Bowlby, 1969; Cassidy, Ehrlich \& Sherman, 2014). Learning, for example, that other people can be relied upon to regulate emotional or biological needs. Having these models in mind could assist individuals to notice, gather and interpret information concerning another social agent (e.g., caregiver, peers, and romantic partners), influencing whether infants respond to others positively. These models also provide infants with information about themselves, for example, sending the message that their needs are important, and so facilitating self-esteem. For this reason, Ainsworth (1978), along with Bowlby's attachment theory, believed that primary caregivers played a key role in shaping the infant's personality and character (Lee, 2003). Early attachment experiences can be qualitatively favourable or unfavourable, needs are met, partially met, or unmet, prompting secure or insecure attachment (Shore, 2010). However, early attachment is open to change, which means if a caring, reciprocal, affectionate relationship is missing, psychotherapeutic interventions can be applied. In short, the role of parents is imperative because as primary caregivers, they need to assure a supportive environment where children could develop smoothly. 


\section{The importance of}

\section{parental attachment relationships}

Having a strong, positive, supportive relationship between caregiver and child is a biologically driven instinct of every human being. Since their delivery to the world, infants attach to their caregivers (Bowlby, 1969). Whenever infants experience threats and discomforting feelings, the caregiver's role is to respond and remove the cause of distress (Prior \& Glaser, 2006). Consequently, infants see their primal caregiver as a haven who is protecting the infant and keeping $\mathrm{him} /$ her safe. In the early years of life, infants are trying to master all the attachment-related information from their environment. Infants are learning whether they are accepted or unaccepted by the attachment figures through their behaviours (e.g., showing caring and responsive attitude towards a baby will suggest accepted relationship). This knowledge later will contribute to their self-image in a form that they will be able to see themselves as a person who whether or not meant to be loved and valued by other social agents (Dykas \& Cassidy, 2011). Moreover, early experiences can lead to encouraging individuals to build relationship with other social agents (e.g., family members, peers) (Svanberg, 1988).

Formulating a secure attachment is a complex and vital task which comes with great responsibility that involves emotional communications and interactive regulation (Shore, 2010). For this reason, ensuring attuned and responsive caregiving, especially in the first year of life, is essential. A lack of sensitive caring can lead to fragile attachment and could result serious implications (e.g. poor mental health, difficulties in emotional regulation) on further development. Examination of the quality of attachment between caregiver and child usually measured from 12 months, as this is the phase of the clearcut attachment or in other words, secure base behaviour phase when children will show signs of separation anxiety being away from their primary caregiver (Bowlby, 1969). Parents are often regulators of their child's environment; thus, emotional regulatory interactions play a crucial part in the child's learning process about self-regulation (Ziabreva, Poeggel, Schnabel \& Braun, 2003). Growing up in an environment where a secure attachment is not attainable and supportive, sensitive caring is missing could have a significant impact on children emotional regulation (Howe, 2005). Likewise, insecure attachment has shown to be linked to a disruption in cognitive and behavioural development (Belsky, 2001), and seem to be associated with a wide range of mental illness as well (i.e., personality disorder, depression, anxiety, self-harm in adulthood) (Weich, Patterson, Shaw, \& Stewart-Brown, 2009). In contrast, maintaining warm, reciprocal interaction will determine the infant's 
emotional wellbeing, capacity to regulate, sense of self and brain development (Shore, 2010). Drawing upon these findings, accessing the secure base between infant and caregiver is developmentally significant as it is the foundation of the child's future social, emotional and cognitive development.

A child's primary caregiver, and first attachment figure, is typically their mother (Lee, 2003), and there is evidence that maternal mental health can affect the quality of the attachment relationship. Postnatal depression, as one of the most common mood disorder linked to childbirth affecting 10-20\% of women (Buist \& Bilszta, 2005; Wilkinson \& Mulcahy, 2010). Severe and/or chronic maternal postnatal depression have an unfavourable impact on the mother-child attachment relationship; thus, it is often associated with insecure attachment (Martins \& Gaffan, 2000). Mothers suffering from postnatal depression displayed a lower level of social support, they feel less bonded to their babies and seeing the child more demanding and difficult than the average (Wilkinson \& Mulcahy, 2010). Besides, in a condition like this, the maternal response usually delayed, not consistent and less contingent which could mainly affect the child's development as he/she is not receiving the necessary support to satisfy his/her biological and psychological needs. This mechanism result a reduction of mother's positive, reciprocal and sensitive caregiving due to her condition. However, it is important to note that early relationships between caregiver and child are open to change, which means the application of various psychotherapies or focusing more on joint activities could be able to help parents to achieve a healthy, reciprocal and supportive bond with their child and improve maternal wellbeing (Baradon, 2005; Armstrong, 2013; Armstrong and Howatson, 2015).

Dyadic psychotherapy offers an opportunity to examine the impact on the caregiver-infant relationship. Several different dyadic psychotherapy approaches exist in the literature. While some techniques are focusing on maximising the interaction between caregiver and infant by talking through the baby (James \& Ritchie, 2013), others are trying to help parents process emotions regarding the infant. Art therapy is one of the psychotherapy approaches that focus on parental responsiveness and attunement (Brandon, 2005) by using art materials (ShamriZeevi, Regev \& Snir, 2019) and sensory experiences (Hosea, 2006; Hall, 2008). Art therapy and participative art activities are assuring an environment where parents have a chance to engage with art materials, discussing art-making and several creative processes with the therapist. At the same time, they are also able to explore their own and the children's behaviour. It is a process of creative experiences, including non-verbal 
and symbolic self-expression (Proulx, 2003). Art therapy and participative art activities provide space to learn about emotional regulation by using artmaterials, reflecting the babies, practising mirroring or talking about feelings, while it strengthens physical support (Armstrong, 2013, 2015; Parashak, 2008; Proulx, 2000, 2003; Hosea, 2006; Meyerowitz-Katz, 2017). In addition, regular participation in art therapy based interventions have shown to be effective ways to improve maternal mental health (Arroyo \& Fowler, 2013) which according to attachment studies (Belsky, 2001; Hogan, Sheffield \& Woodward, 2017; Mikulincer \& Florian, 1999) affect child's mental health as well. Importantly, although a therapeutic approach may be necessary to address disrupted attachment, among all the variations of psychotherapeutic approaches, the central premise of art therapy is simply that participating in a joint activity with your child is sufficient to build optimal attachment, and to learn about self and other.

\section{Self-awareness - the development of the self-concept}

Self-awareness is a multifaceted and dynamic process. The concept of the self is considered to be fundamental to the development of human cognition and interaction. Without self-concept, there would be no concept of 'me' as distinct from the concept of 'you' (Ross,
Anderson \& Campbell, 2011). At the age of 2-3 years, children are becoming more and more self-consciousness over their environment. Signs of self-awareness are present in activities like recognising themselves in the mirror or a picture (Amsterdam, 1972; Nielsen, Suddendorf, \& Slaughter, 2006; Courage, Edison \& Howe, 2004), utilising self-referential words or personal pronouns (Rochat, Broesch \& Jayne, 2012; Turk, GillespieSmith, Krigolson, Harvard, Conwy \& Cunningham, 2015). According to Rochat (2003), children are going through five different levels to develop their sense of self-awareness. The development of selfawareness can be described as a gradually improving process with levels expended from the perception of the self to an evaluation of the self as perceived by others.

In the description of Rochat (2003), five levels are distinguished. Level 0 implies the entire absence of self-awareness. The first two levels (Level 1 and 2) are referring to implicit self-awareness. At Level 1 (from birth to 6 months), children sense that there is a perfect contingency between seen and felt movements, or in other words, the differentiated self is expressed. At Level 2 (at the age of 6 months), they can go beyond the felt and seen movement on the other surface. They have cognitively identified themselves as an object in the environment, and they are aware that the image is out there on a surface. In other 
words, a situated self is expressed. Finally, explicit self-awareness is thriving from level 3 to 5. This process happens gradually, as firstly children demonstrate their ability of recognition. At level 3 (from 12 months up to the age of 3), there is an identification between the displayed and real body image. Children are able to identify the image in the mirror, which is consistent with the idea of 'me'. This phase is followed by Level 4 (at the age of 4 years) - with the permanent self - when the entity goes beyond the here and now. Children possess the capability to recognise themselves in pictures, video footages taken in the past. Hence, time and appearance became invariant. Lastly, at Level 5 (around the age of 5), the selfconscious self is expressed, as children are able to recognise themselves from the first and third person as well. Individuals became aware of what they are in others' minds - followed by the process of selfevaluation of how the self is proceeded and valued by others. An essential part of the discussion about self-awareness is how children evaluate others in mind. By the age of $4-5$, children begin to be able to hold off multiple representations and observations on objects and people.

Importantly, learning about the self, and distinguishing self from others is likely to rely on social interactions. A child whose needs are met with timely, positive and sensitive responses, will learn that they are an effective social agent. This mechanism can be demonstrated by the still face response designed by Tronic and colleagues (1978). The goal of the still face paradigm to examine how infants react to the violation of social contingencies in the face to face interaction with their main caregiver. The task consists three face to face interaction: (1) a normal interaction episode, (2) the still face episode with an adult being unresponsive and maintaining neutral facial expression, (3) lastly, a reunion when the adult continues to act normally in the social interaction. The importance of this paradigm that it evokes changes in the infant's behaviour called the still-face effect. The second phase usually very stressful for the infant who as a result presenting the still-face effect including heightened negative emotionality, increased avoiding behaviour (e.g., avoid eye contact) and reduction in social engagement (e.g., showing less smile). Several studies have found a link using the still face paradigm with the quality of parental caregiving, but also linked it to future adaptations, like attachment quality (Miron, Lewis \& Zeanah, 2009) or behaviour problems (Kaitz et al., 2010). The application of this paradigm suggests that very young children could be sensitive to social contingency and except that the caregiver gives a constant, socially contingently responsive way of face to face interactions.

Essentially, by reacting with distress when mother's stop responding to them, 
an infant is indicating that they expected a positive response, and are mourning its loss. This could be due to the loss of connection, but also due to the insult to the child's sense of agency. Infants have similar reactions to the breakdown of contingency in non-social interactions for example reacting with distress when a stimulus they once controlled with their own body movements (such as a pleasant sound activated by an arm movement) stops sounding or stops sounding under their control (Lewis, Alessandri \& Sullivan, 1990). This implies that part of the child's enjoyment of reciprocal exchange comes from their enjoyment of their own agency - the first step on a journey to mature self-awareness. Interestingly, infants of mothers with postnatal depression show a reduced still face response (Field, Nadel, HernandezReif, Diego, Vera \& Sanders, 2005), suggesting that their expectations of social connection and agency are less strong, possibly due to a decreased number of reciprocal interactions. For instance reading together with the child offers countless benefits on the child's early development. Provided that reading is a social process, those pairs who are spending more time together inevitably began to connect more. As a result, the shared time and joint activity are becoming an enjoyable part of their routine. However, it is important to note that there are cultural and social variables that could influence the frequency and quality of book reading (Bus, 2001) that will affect how the activity will contribute the development of self-concept. Those parents who are readers themselves are more likely to pass on the enthusiasm towards reading and books while evoking child's interest and encouraging social engagement and enhancing internal personal development (Howard, 2011). The study of Howard (2011) says that by reading teens and children gain significant insight into self-identification, selfconstruction and self-awareness. The different stories can have a psychological value by showing them that others have been in the same situation as them before. For that reason, it means that referential information in books potentially has the power to expand the concept of the self and develop children's self-awareness. These observations suggest that in addition to supporting early attachment, joint activities could be important for the formation of a robust sense of self as they premise a place for expanding the knowledge about the self and others.

\section{Prosocial behaviour}

Empathy and positive social interactions are playing an important role in human's life.

From birth, infants react to other's distress signal with personal distress (Geangu, Benga, Stahl \& Striano, 2010; Dondi, Simion \& Caltran, 1999). During the child's moral development, children have to distinguish between their own 
and other's distress, by doing so they also learn to alleviate their innate emphatic distress or concern to achieve other's goals by focusing on other's need (Hoffman 2000; Ross, 2017). Caregivers are key figures of their children's developmental and socialisation process, as they are the first reference figures who are teaching them about empathy, helping, sharing and comforting (Mussen \& Eisenberg, 2001). As evidence to the previous findings, the study of Farrant and colleagues (2012) has shown that mothers who have a higher level of maternal empathy will be more likely to encourage their children to take perspective on others and show more prosocial behaviours. The development of prosocial behaviours is begun in infancy when the caregiver-infant socioemotional reciprocity and responsiveness creates a kind of emotional empathy (Kochanska, Forman \& Coy, 1999). Maternal empathy and socio-emotional availability affect the child empathic and prosocial behaviour patterns and will also impact how children are dealing with distress later on (Farrant, Devine, Maybery \& Fletcher, 2012). Furthermore, research has shown that parenting styles can also affect children's prosocial behaviour. Maternal warmth, responsiveness and inductive discipline have been related to a higher level of prosocial behaviour (Knafo \& Plomin, 2006,) while punitive parenting has been found to relate to a lower level of prosocial behaviour (Romano, Tremblay, Boulerice \& Swisher, 2005).

Interestingly, research has shown that helping behaviour has a self-regulatory function, as two year -old's affective arousal has been increasing on witnessing another person's need, and decreasing when the need is resolved (Hepach, Vaish \& Tomasello, 2012). This finding demonstrates that sensitivity to others needs is reciprocal and that joint activity need not always focus on the child's goals. Importantly, as reflected in early discussion of attachment, positive social behaviour is modelled within joint activities, and with increasing age, the child must learn to balance their own needs with those of others - sharing, helping and comforting. Research has shown that these prosocial behaviours are predicted by secure attachment (Kochanska, Forman, Aksan \& Dunbar, 2005). Prosocial behaviour refers to the instrumental helping, sharing and comforting others. Helping throughout the art-making process requires the recognition of how to assist infant achieving his/her goal by giving the necessary resources for another's benefit and/or responding emphatically to understand the causes of other's sadness or distress (Thompson \& Newton, 2013). LeRoux and Bernadska (2014) have found that art participation foster helping behaviours towards others. Previous research has also shown that caregivers who demonstrated a higher level of 
maternal empathy, responsiveness, and socio-emotional availability were more likely to raise children with the more prosocial trait (Farrant et al., 2012). In addition to that, the social-emotional domain also associated with the development of positive, social bonds with other agents (Dunn \& Hughes, 2001). Hence, parents who participated in regular art activities in any form (e.g., painting, singing, dancing, laying with toys) with their children have reported that their children have stronger and more sophisticated social skills than those parents who interacted with their child less frequently (Muñiz et al., 2014). During the social-emotional development, social skills are continually improving (Spinrad et al., 2006). The usage of different art materials could serve as a likely explanation of the link between art participation and prosociality. The application of art materials is not only presented as an invitation to parents and children to engage with a task (Armstrong \& Howatson, 2015; Proulx, 2003), but also a representation of several types of equipment to encourage the dyads to learn about helping and sharing. In the case of small accidents (paints on clothes, water on a finished piece of art) showing signs of sympathy and comfort could be built in their ways of thinking about social interactions and they can re-apply the acquired behaviour in other situations as well. Since secure attachment is premised on a reciprocal exchange, and joint activities offer a natural starting point to balance own and others' goals, it stands to reason that positive social behaviour may also be scaffolded by joint activities. Therefore participating in various forms of joint-activities assume that children could acquire the basic concepts of prosocial behaviour through different material usage and social interactions.

\section{Discussion}

Given the current predictors, attachment, self-awareness, and prosociality include societal importance as they mainly depend on social interactions - that could contribute to the children's development. Although the above mentioned three predictor variables rarely appear together in literature reviews a positive association presumably would have been found between them. In other words, self-awareness, prosociality and parental attachment could be able to affect one another positively. Gillath and Karantzas (2015) suggested that a robust sense of self and/or secure attachment could potentially increase prosocial behaviour. Supporting the previous finding, other research came to the same conclusion by saying that caring and reciprocal attachment relationship will foster a higher level of self-awareness and could assist the improvement of prosociality (Bozeman, 2014; Thompson, Laible, Padilla-Walker \& Carlo, 2019). Prosocial acts are often encouraged by culture; hence the sense of belongingness 
is an important factor to be considered. Consequently, in cases when the attachment has supported the willingness to act prosaically will induce (Twenge, Baumeister, DeWell, Ciarocco \& Bartels, 2007). For building a robust sense of self, children are acquiring knowledge about their own perceptions and experiences, while trying to comprehend other's behaviour and value system. Scaffolding a secure attachment is also imperative because it is mainly affecting children's first representations of the world by encouraging them to discover on their own. Assuring them positive, reciprocal relationships, caring attitude will have various positive outcomes regarding the child's emotional and cognitive development (e.g., a higher level of self-regulation, self-esteem, and better mental language set, logical thinking). In order to get greater insight into the early developments of the above- mentioned variables, home-based joint activities could have been promising starting points for further examinations.

\section{References}

Ainsworth, M. D. S. (1978). Patterns of attachment: a psychological study of the strange situation. New York, Hillsdale, N.J.: Lawrence Erlbaum Associates

Amsterdam, B. (1972). Mirror self-image reactions before age two. Developmental Psychobiology: The Journal of the International Society for Developmental
Psychobiology, 5(4), 297-305. doi: 10.1002/dev.420050403

Armstrong, V. G. (2013). Modelling attuned relationships in art psychotherapy with children who have had poor early experiences. The Arts in Psychotherapy, 40, 275-284. doi: 10.1016/j.aip.2013.04.002

Armstrong, V. G., \& Howatson, R. (2015). Parent-infant art psychotherapy: a creative dyadic approach to early intervention. Infant mental health journal, 36, 213-222. doi: 10.1002/imhj.21504

Arroyo, C., \& Fowler, N. (2013). Before and after: A mother and infant painting group. International Journal of Art Therapy, 18(3), 98-112. doi: $\underline{10.1080 / 17454832.2013 .844183}$

Baradon, T. (Ed.). (2005). The practice of psychoanalytic parent-infant psychotherapy: Claiming the baby. Hove, England: Routledge.

Belsky, J. (2001). Emanuel Miller Lecture: Developmental risks (still) associated with early child care. The Journal of Child Psychology and Psychiatry and Allied Disciplines, 42(7), 845-859. doi: 10.1111/1469-7610.00782

Bowlby, J. (1969). Attachment and loss, Volume 1, Attachment. London: Hogarth Press.

Bowlby, J. (1973). Attachment and loss: Volume II: Separation, anxiety and anger. In Attachment and Loss: Volume II: Separation, Anxiety and Anger (pp. 1-429). London: The 
Hogarth press and the institute of psycho-analysis.

Bozeman, S. (2014). Attachment and Selfesteem: Implications for Prosociality and the Self. Doctoral Dissertation, University of Oklahoma.

Buist, A., \& Bilszta, J. (2005). Beyondblue National Postnatal Depression Program, Volume 1: National screening program. Retrieved June 29, 2020 from https://www.beyondblue.org.au/docs Ldefault-source/8.-perinataldocuments/bw0075-reportbeyondblue-national-researchprogram-vol2.pdf?sfvrsn=2

Bus, A. G. (2001). Joint caregiver-child storybook reading: A route to literacy development. Handbook of early literacy research, 1, 179-191.

Cassidy, J., Ehrlich, K. B., \& Sherman, L. J. (2014). Child-parent attachment and response to threat: A move from the level of representation. In Attachment Pre-Conference of the meetings of the Society for Research in Child Development, Mar, 2009, Denver, CO, US; Portions of this paper were presented at the aforementioned conference.. American Psychological Association.

Courage, M. L., Edison, S. C., \& Howe, M. L. (2004). Variability in the early development of visual selfrecognition. Infant Behavior and Development, 27(4), 509-532. doi: 10.1016/j.infbeh.2004.06.001
Dondi, M., Simion, F., \& Caltran, G. (1999). Can newborns discriminate between their own cry and the cry of another newborn infant?. Developmental psychology, 35(2), $418 . \quad$ doi: $\underline{10.1037 / 0012-1649.35 .2 .418}$

Dunn, J., \& Hughes, C. (2001). "I got some swords and you're dead!": Violent fantasy, antisocial behavior, friendship, and moral sensibility in young children. Child development, 72(2), 491-505. doi: 10.1111/1467$\underline{8624.00292}$

Dykas, M. J., \& Cassidy, J. (2011). Attachment and the processing of social information across the life span: theory and evidence. Psychological bulletin, 137(1), $19 . \quad$ doi: $10.1037 / \mathrm{a} 0021367$

Farrant, B. M., Devine, T. A., Maybery, M. T., \& Fletcher, J. (2012). Empathy, perspective taking and prosocial behavior: The importance of parenting practices. Infant and Child Development, 21(2), 175-188. doi: 10.1002/icd.740

Field, T., Nadel, J., Hernandez-Reif, M., Diego, M., Vera, Y., Gil, K., Sanders, C. (2005). Depressed mothers' infants show less negative affect during noncontingent interactions. Infant Behavior and Development, 28, 426-430. doi: 10.1016/j.infbeh.2005.03.003

Geangu, E., Benga, O., Stahl, D., \& Striano, T. (2010). Contagious crying beyond the first days of life. Infant Behavior and Development, 33(3), 279288. doi: $10.1016 /$ j.infbeh.2010.03.004 
Gillath, O., \& Karantzas, G. (2015). Insights into the formation of attachment bonds from a social network perspective. In Bases of adult attachment, 131-156. Springer, New York, NY. doi: 10.1007/978-1-46149622-9 7

Hall, P. (2008). Painting together: An art therapy approach to mother-infant relationships.

Hepach, R., Vaish, A., \& Tomasello, M. (2012). Young children are intrinsically motivated to see others helped. Psychological science, 23(9), 967972. doi: $10.1177 / 0956797612440571$

Hoffman, M. L. (2000). Empathy and moral development.Implications for caring and justice. Cambridge, UK: Cambridge University Press.

Hogan, S., Sheffield, D., \& Woodward, A. (2017). The value of art therapy in antenatal and postnatal care: A brief literature review with recommendations for future research. International Journal of Art Therapy, 22(4), 169-179. doi: $\underline{10.1080 / 17454832.2017 .1299774}$

Hosea, H. (2006). "The Brush's Footmarks": Parents and infants paint together in a small community art therapy group. International Journal of Art Therapy, 11, 69-78. doi: $\underline{10.1080 / 17454830600980317}$

Howard, V. (2011). The importance of pleasure reading in the lives of young teens: Self-identification, selfconstruction and self- awareness. Journal of Librarianship and Information Science, 43(1), 46-55. doi: 10.1177/0961000610390992

Howe, D. (2005). Child abuse and neglect: Attachment, development and intervention. Macmillan International Higher Education.

James, J., \& Ritchie, S. (2013). Using groups to strengthen parent-infant relationships: A training workshop. Anna Freud Centre, London, February Kaitz, M., Maytal, H. R., Devor, N., Bergman, L., \& Mankuta, D. (2010). Maternal anxiety, mother-infant interactions, and infants' response to challenge. Infant Behavior and Development, 33(2), 136-148. doi: 10.1016/j.infbeh.2009.12.003

Knafo, A., \& Plomin, R. (2006). Parental discipline and affection and children's prosocial behavior: Genetic and environmental links. Journal of personality and social psychology, 90(1), 147. doi: 10.1037/0022-3514.90.1.147

Kochanska, G., Forman, D. R., Aksan, N., \& Dunbar, S. B. (2005). Pathways to conscience: Early mother-child mutually responsive orientation and children's moral emotion, conduct, and cognition. Journal of child psychology and psychiatry, 46(1), 19-34. doi: 10.1111/j.1469-7610.2004.00348.x

Lee, E. J. (2003). The attachment system throughout the life course: Review and criticisms of attachment theory. USA: Rochester Institute of Technology. Retrieved July 30, $2020 \quad$ from 
http://personalityresearch.org/papers lee.html

LeRoux, K., \& Bernadska, A. (2014). Impact of the arts on individual contributions to US civil society. Journal of Civil Society, 10(2), 144-164. doi: $\underline{10.1080 / 17448689.2014 .912479}$

Lewis, M., Alessandri, S. M., \& Sullivan, M. W. (1990). Violation of expectancy, loss of control, and anger expressions in young infants. Developmental Psychology, 26(5), 745.

Martins, C., \& Gaffan, E. A. (2000). Effects of early maternal depression on patterns of infant-mother attachment: A meta-analytic investigation. Journal of Child Psychology and Psychiatry,41(6), 737-746. doi: 10.1111/1469-7610.00661

Meyerowitz-Katz, J. (2017). The crisis of the cream cakes. Art therapy in the early years: Therapeutic interventions with infants, toddlers and their families, 118-132.

Mikulincer, M., \& Florian, V. (1999). Maternal-fetal bonding, coping strategies, and mental health during pregnancy-the contribution of attachment style. Journal of Social and Clinical Psychology, 18(3), 255-276. doi: 10.1521/jscp.1999.18.3.255

Miron, D., Lewis, M. L., \& Zeanah, C. H. (2009). Clinical use of observational procedures in early childhood relationship assessment. Handbook of infant mental health, 252-265.
Muñiz, E. I., Silver, E. J., \& Stein, R. E. (2014). Family routines and socialemotional school readiness among preschool-age children. Journal of Developmental \& Behavioral Pediatrics, 35(2), 93-99. doi: 10.1097/DBP.0000000000000021

Mussen, P., \& Eisenberg, N. (2001). Prosocial development in context. In A. C. Bohart \& D. J. Stipek (Eds.), Constructive \& destructive behavior: Implications for family, school, \& society. 103-126. American Psychological Association.

Nielsen, M., Suddendorf, T., \& Slaughter, V. (2006). Mirror self-recognition beyond the face. Child Development, 77(1), 176-185. doi: 10.1111/i.1467-8624.2006.00863.x

Parashak, S. T. (2008). Object relations and attachment theory: Creativity of Mother and Child in the Single Parent Family. In J. Kerr, Christine and Hoshino (Ed.), Family Art Therapy: Foundations of Theory and Practice. (pp 65-93). Routledge.

Prior, V., \& Glaser, D. (2006). Understanding attachment and attachment disorders theory, evidence and practice. London, Philadelphia: Jessica Kingsley Publishers.

Proulx L. (2000). Container, contained, containment: group art therapy with toddlers 18 to 30 months and their parent. Canadian Art Therapy Association Journal, 14, 3-6. doi: $\underline{10.1080 / 08322473.2000 .11432243}$ 
Proulx, L. (2003). Strengthening emotional ties through parent-child-dyad art therapy interventions with infants and preschoolers. London: Jessica Kingsley.

Rochat, P. (2003). Five levels of selfawareness as they unfold early in life. Consciousness and cognition, 12(4), 717731. doi: 10.1016/S10538100(03)00081-3

Rochat, P., Broesch, T., \& Jayne, K. (2012). Social awareness and early selfrecognition. Consciousness and cognition, 21(3), 1491-1497. doi: 10.1016/i.concog.2012.04.007

Romano, E., Tremblay, R. E., Boulerice, B., \& Swisher, R. (2005). Multilevel correlates of childhood physical aggression and prosocial behavior. Journal of abnormal child psychology, 33(5), 565-578. doi: $\underline{10.1007 / \mathrm{s} 10802-005-6738-3}$

Ross, J. (2017). You and me: investigating the role of self-evaluative emotion in preschool prosociality. Journal of Experimental Child Psychology, 155, 6783. doi: $10.1016 /$ j.jecp.2016.11.001

Ross, J., Anderson, J. R., \& Campbell, R. N. (2011). Situational changes in selfawareness influence 3-and 4-year-olds' self-regulation. Journal of experimental child psychology, 108(1), 126-138. doi: 10.1016/j.jecp.2010.08.003

Shamri-Zeevi, L., Regev, D., \& Snir, S. (2019). Art-based parental training (ABPT)-parents' experiences. International Journal of Art Therapy,
24(4),

192-201.

doi:

$\underline{10.1080 / 17454832.2019 .1641117}$

Shore, A.N. (2010). Relational trauma and the developing right brain: The neurobiology of broken attachment bonds. In Baradon T. (Ed.) Relational Trauma in Infancy Psychoanalytic, Attachment and Neuropsychological Contributions to Parent-Infant Psychotherapy (pp. 19-47). London, New York: Taylor \& Francis.

Spinrad, T. L., Eisenberg, N., Cumberland, A., Fabes, R. A., Valiente, C., Shepard, S. A., ... \& Guthrie, I. K. (2006). Relation of emotion-related regulation to children's social competence: a longitudinal study. Emotion, 6(3), 498. doi: $\underline{10.1037 / 1528-3542.6 .3 .498}$

Svanberg, P. O. (1998). Attachment, resilience and prevention. Journal of Mental Health, 7(6), 543-578. doi: $\underline{10.1080 / 09638239817716}$

Thompson, R. A., \& Newton, E. K. (2013). Baby altruists? Examining the complexity of prosocial motivation in young children. Infancy, 18(1), 120-133. doi: $\quad \underline{10.1111 / j .1532-}$ 7078.2012.00139.x

Thompson, R. A., Laible, D., PadillaWalker, L. M., \& Carlo, G. (2019). Early moral development and attachment theory. The Oxford handbook of parenting and moral development, 21.

Tronick, E., Als, H., Adamson, L., Wise, S., \& Brazelton, T. B. (1978). Infants response to entrapment between 
contradictory messages in face-to-face interaction. Journal of the American Academy of Child and Adolescent Psychiatry, 17, 1-13. doi: 10.1016/S0002-7138(09)62273-1

Turk, D. J., Gillespie-Smith, K., Krigolson, O. E., Havard, C., Conway, M. A., \& Cunningham, S. J. (2015). Selfish learning: The impact of selfreferential encoding on children's literacy attainment. Learning and instruction, 40, 54-60. doi: $\underline{10.1016 / \text { j.learninstruc.2015.08.001 }}$

Twenge, J. M., Baumeister, R. F., DeWall, C. N., Ciarocco, N. J., \& Bartels, J. M. (2007). Social exclusion decreases prosocial behavior. Journal of personality and social psychology, 92(1), 56. doi: 10.1037/0022-3514.92.1.56

Weich, S., Patterson, J., Shaw, R., \& Stewart-Brown, S. (2009). Family relationships in childhood and common psychiatric disorders in later life: systematic review of prospective studies. The British Journal of Psychiatry, 194(5), 392-398. doi: 10.1192/bjp.bp.107.042515

Wilkinson, R. B., \& Mulcahy, R. (2010). Attachment and interpersonal relationships in postnatal depression. Journal of Reproductive and Infant Psychology, 28(3), 252-265. doi: $\underline{10.1080 / 02646831003587353}$

Ziabreva, I., Poeggel, G., Schnabel, R., \& Braun, K. (2003). Separation-induced receptor changes in the hippocampus and amygdala of Octodon degus: influence of maternal vocalisations. Journal of Neuroscience, 23(12), 5329-5336. doi: 10.1523/JNEUROSCI.23-12$\underline{05329.2003}$ 